\title{
VERIFIKASI METODE PENGUJIAN DENSITAS CRUDE PALM OIL MENGGUNAKAN STANDAR ISO 6883:2017
}

\author{
Verification of Testing Method for Crude Palm Oil Density \\ Using Standard ISO 6883:2017
}

\author{
Febrian Isharyadi ${ }^{1}$, Azis B. Sitanggang ${ }^{1,2}$, Didah Nur Faridah ${ }^{1,2}$ dan Nuri Andarwulan ${ }^{1,2}$ \\ ${ }^{1}$ Departemen IImu dan Teknologi Pangan, Fakultas Teknologi Pertanian, Institut Pertanian Bogor, Kampus IPB \\ Dramaga, PO Box 22016002 Bogor, Jawa Barat, Indonesia \\ ${ }^{2}$ Southeast Asian Food Science and Agriculture Science and Technology (SEAFAST) Center, IPB University \\ e-mail: didah_nf17@yahoo.com
}

Diterima: 28 Februari 2019, Direvisi: 10 April 2019, Disetujui: 29 April 2019

\begin{abstract}
Abstrak
Densitas merupakan parameter penting dari suatu produk khususnya dalam perdagangan yang menggunakan volume sebagai basis pengukuran jumlah. Penggunaan berbagai metode uji densitas yang harmonis menghasilkan data hasil uji yang saling mendekati sehingga tidak ada yang dirugikan baik dari pihak penjual maupun pembeli. Metode uji merupakan salah satu faktor penting yang menentukan kualitas dan keabsahan suatu hasil pengujian. Pada penelitian ini, verifikasi metode pengujian densitas dilakukan untuk menguji nilai densitas pada lemak atau minyak yang berasal dari hewan atau tumbuhan berdasarkan standar ISO 6883:2017 tentang determination of conventional mass per volume (litre weight in air). Hingga saat ini belum diketahui performa metode uji tersebut pada aplikasinya untuk produk CPO khususnya di Indonesia. Maka diperlukan verifikasi terhadap metode uji ISO 6883:2017 untuk pengujian densitas pada crude palm oil (CPO) di Indonesia untuk memastikan metode tersebut memiliki kualitas yang baik dan data yang dihasilkan dijamin keabsahannya. Verifikasi metode dilakukan melalui parameter akurasi menggunakan certified reference material (CRM) yang telah diketahui nilai densitasnya dan parameter presisi dengan menggunakan sampel CPO pada suhu $50^{\circ} \mathrm{C}$. Hasil verifikasi metode menunjukkan bahwa nilai akurasi metode tersebut adalah $99.44 \%$ dengan nilai rata-rata hasil pengujian densitas CRM adalah $0.8611 \mathrm{~g} / \mathrm{mL}$ dan nilai simpangan baku relatif $0.08 \%$, sedangkan untuk parameter presisi diperoleh rata-rata nilai densitas CPO $0.8867 \mathrm{~g} / \mathrm{mL}$ dengan simpangan baku relatif $0.35 \%$. Hasil tersebut menunjukkan bahwa metode uji ISO 6883:2017 memiliki kualitas dan performa yang baik dalam melakukan pengujian densitas pada produk CPO. Metode tersebut dapat digunakan sebagai metode rutin untuk pengujian densitas CPO dan sebagai acuan dalam penyusunan standar CPO.
\end{abstract}

Kata kunci: densitas, ISO 6883 : 2017, CPO, verifikasi, metode uji

\begin{abstract}
Density is an important parameter of a product, especially in trading that uses volume as the basis for measuring quantities. The use of harmonious density test method will produce test result that are close each other so that no one harmed either from the seller or buyer. Test method is one of the important factors that determine the quality and validity of a test result. In this study, verification of testing method was carried out to test the density values of fats or oils originating from animals or plants based on ISO 6883:2017 standard on determination of conventional mass per volume (litre weight in air). The performance of the test method has not yet been known in its application for CPO products, especially in Indonesia. Therefore verification of the ISO 6883:2017 test method for measurement of density on CPO in Indonesia is required. This is done to ensure that the method is good at quality and the data result is guaranteed validity. Method verification is done through accuracy parameters using certified reference material (CRM) which has known the value of density and precision parameters using CPO, both samples are testing at $50^{\circ} \mathrm{C}$. The results show that the accuracy of the method is $99.44 \%$ with the average value of the CRM density is $0.8611 \mathrm{~g} / \mathrm{mL}$ and relative standard deviation value $0.08 \%$, while for the precision parameter the average CPO density value is $0.8867 \mathrm{~g} / \mathrm{mL}$ with relative standard deviation $0.35 \%$. These results indicate that the ISO 6883:2017 test method has good quality and performance in conducting density testing on CPO products. This method can be used as a routine method for testing CPO density and as a reference for arrange CPO standards.
\end{abstract}

Keyword: density, ISO 6883 : 2017, CPO, verification, test method

\section{PENDAHULUAN}

Pemanfaatan Crude Palm Oil (CPO) saat ini sangat luas, diantaranya sebagai bahan baku produksi berbagai macam jenis produk pangan maupun non-pangan (Ayustaningwarno, 2012). Konsumsi CPO dunia pun meningkat setiap tahunnya (Abdullah, 2011) karena dalam CPO 
mengandung banyak zat gizi dan mikronutrien yang dibutuhkan tubuh manusia seperti lemak, vitamin E dan karotenoid (Ulfah et al., 2016). Indonesia merupakan salah satu negara penghasil CPO terbesar di dunia (Mariati, 2009 ; Nasution et al, 2015). Produksi CPO Indonesia pada tahun 2017 mencapai 35.47 juta ton (Badan Pusat Statistik, 2017). Berdasarkan data produksi tersebut, CPO telah menjadi salah satu komoditi perdagangan yang strategis bagi Indonesia disamping minyak dan gas bumi (Widyaningtyas dan Widodo, 2016).

Salah satu parameter penting dalam perdagangan CPO adalah densitas. Densitas merupakan suatu ukuran massa per unit volume suatu zat (Kadir et al, 2017) yang diukur pada suhu tertentu. Nilai densitas suatu zat sangat dipengaruhi oleh suhu pengukuran dari zat tersebut (American Standard Testing and Material, 2018). Nilai densitas umumnya dapat menggambarkan karakteristik fisikokimia CPO dan hadirnya komponen kontaminan yang dapat menurunkan kualitas dari CPO (Hastono et al, 2010). Dalam perdagangannya, harga CPO ditentukan berdasarkan berat dari CPO itu sendiri dan pengukuran berat CPO dilakukan berbasis volume (Tan dan Nehdi, 2012). Oleh karena itu, nilai densitas dari CPO yang akan diperdagangkan tersebut akan sangat sangat menentukan berat dari CPO (Hasibuan, 2012)

Dalam rangka menjamin hasil pengujian yang akurat, diperlukan metode pengujian yang stadar dan harmonis antara pembeli dan penjual agar hasil dari pengujian tersebut tidak menimbulkan kerugian bagi salah satu pihak. Pada perdagangan secara internasional terdapat standar internasional terkait spesifikasi densitas dari CPO, namun beberapa negara mempersyaratkan spesifikasi berbeda terkait parameter densitas (Tabel 1). Beberapa negara mempersyaratkan densitas dalam bentuk apparent density (massa per satuan volume pada suhu tertentu), sedangkan negara lain ada yang mempersyaratkan dalam bentuk relative density (perbandingan densitas suatu material pada suhu tertentu dengan densitas air pada suhu tertentu). Kedua jenis densitas tersebut pun telah diatur dalam Codex yang merupakan standar internasional untuk pangan (Codex Allimentarius, 2017). Perbedaan metode uji densitas yang digunakan akan berpotensi menghasilkan hasil pengujian yang berbeda dan berpengaruh terhadap jumlah CPO yang diperdagangkan. Organisasi internasional untuk standardisasi (ISO) telah menetapkan metode uji untuk menentukan nilai densitas yaitu ISO 6883:2017 tentang animal and vegetable fats and oils - determination of conventional mass per volume (litre weight in air) (International Organization of Standardization, 2017a). Standar tersebut merupakan standar metode uji yang telah disepakati melalui konsensus secara internasional dalam pengujian densitas untuk sampel lemak dan minyak yang bersumber dari hewan dan tumbuhan. Pada penelitian ini pengujian densitas dari CPO menggunakan metode uji tersebut.

Pengujian merupakan suatu proses penentuan satu atau lebih karakteristik atau mutu dari suatu produk (Adinugroho et al., 2016). Kualitas dan keabsahan dari suatu pengujian dan data yang dihasilkan di laboratorium disebabkan oleh beberapa faktor, salah satunya adalah metode uji yang digunakan (Rambla-Alegre et al., 2012 ; Andarwulan et al. 2014). Salah satu metode yang dapat digunakan untuk menilai apakah suatu metode uji berkualitas dan mampu menghasilkan data yang valid adalah dengan melakukan validasi atau verifikasi. Kedua parameter ini dianggap penting karena menunjukkan performa hasil pengujian yang dilakukan apakah sesuai dengan target dan tujuan dari suatu proses pengujian (International Organization of Standardization, 2017b). Verifikasi metode uji dilakukan apabila telah tersedia metode spesifik yang dijadikan acuan, sehingga diperlukan pembuktian aplikasi terhadap metode uji tersebut.

Tabel 1 Spesifikasi densitas pada beberapa standar.

\begin{tabular}{|c|c|c|c|c|c|}
\hline Parameter & SNI(1) & $\mathbf{M S}^{(2)}$ & $\mathbf{I S}^{(3)}$ & $\mathbf{G B}^{(4)}$ & Codex ${ }^{(5)}$ \\
\hline $\begin{array}{l}\text { Relative density } \\
\left(\mathrm{x}^{0} \mathrm{C} / \text { air pada } 20\right. \\
\left.{ }^{0} \mathrm{C}\right)^{(\mathrm{a})} \\
\left(\mathrm{x}^{0} \mathrm{C} / \text { air pada } 30\right. \\
\left.{ }^{0} \mathrm{C}\right)^{(\mathrm{b})}\end{array}$ & - & - & $\begin{array}{l}0.900-0.912^{(b)} \\
\text { (pada suhu } 30 \\
{ }^{\circ} \mathrm{C} \text { ) }\end{array}$ & $\begin{array}{l}0.891-0.899^{(a)} \\
\text { (pada suhu } 50 \\
{ }^{0} \mathrm{C} \text { ) }\end{array}$ & $\begin{array}{l}0.891-0.899^{(a)} \\
\left.\text { (pada suhu } 50^{\circ} \mathrm{C}\right)\end{array}$ \\
\hline \multirow[t]{2}{*}{$\begin{array}{l}\text { Apparent density } \\
\left(\mathrm{Kg} / \mathrm{L}^{(\mathrm{c})}, \mathrm{g} / \mathrm{mL}^{(\mathrm{d})}\right)\end{array}$} & - & $\begin{array}{l}0.8889-0.8896 \\
\text { (c) }\end{array}$ & - & - & $\begin{array}{l}0.889-0.895^{(\mathrm{d})} \\
\left(\text { pada suhu } 50^{\circ} \mathrm{C}\right)\end{array}$ \\
\hline & & $\begin{array}{l}\text { (pada suhu } 50 \\
{ }^{0} \mathrm{C} \text { ) }\end{array}$ & & & \\
\hline
\end{tabular}

(sumber : (1) Badan Standardisasi Nasional, 2006 ; (2) Department of Standards Malaysia, 2007 ; (3) Bureau of Indian Standards, 2018 ; (4) China National Standards, 2009 ; (5) Codex Allimentarius, 2017).

keterangan : SNI = Standar Nasional Indonesia

$$
\begin{array}{ll}
\text { MS } & =\text { Malaysia Standard } \\
\text { IS } & =\text { India Standard } \\
\text { GB } & =\text { Guobiao Standard (Chinese national standard) }
\end{array}
$$


Sampai saat ini belum diketahui performa metode uji ISO 6883:2017 untuk pengujian densitas CPO khususnya di Indonesia. Oleh karena itu diperlukan verifikasi atas metode uji ISO 6883:2017 untuk pengujian densitas pada CPO. Hal ini dilakukan untuk mengevaluasi keakuratan dan nilai presisi dari metode uji tersebut sehingga dapat memberi kepastian bahwa metode tersebut memiliki performa yang baik dan mampu menghasilkan data yang akurat. Hal ini akan memberikan dampak pada pengakuan keberterimaan hasil pengujian secara internasional khususnya pada perdagangan, mengingat bahwa CPO merupakan komoditi perdagangan yang strategis bagi Indonesia.

\section{TINJAUAN PUSTAKA}

\subsection{Densitas}

Densitas merupakan suatu ukuran massa per unit volume suatu zat (Chuayjuljit et al., 2007 ; Kadir et al, 2017 ) yang diukur pada suatu suhu tertentu (American Standard Testing and Material, 2018) karena densitas merupakan suatu fungsi dari suhu (Baroutian et al., 2010) Pada minyak, semakin jenuh minyak tersebut maka densitas akan semakin tinggi dan menjadi menurun dengan adanya peningkatan suhu (Baroutian et al., 2010 ; Hasibuan, 2012). Hubungan tersebut dapat digambarkan dengan persamaan :

$\rho=a+6$. T

dimana:

$$
\begin{array}{rll}
\rho & : & \text { densitas }(\mathrm{g} / \mathrm{mL}) \\
\mathrm{T} & : & \text { suhu dari zat }\left({ }^{\circ} \mathrm{C}\right) \\
a & : & \text { intersep } \\
6 & : & \text { slope }
\end{array}
$$

Sumber : (Esteban et al., 2012).

\subsection{Validasi dan Verifikasi metode}

Kualitas dan keabsahan dari suatu analisis di laboratorium disebabkan oleh beberapa faktor, salah satunya adalah metode analisis yang digunakan (lihat Gambar 1). Metode yang digunakan dalam suatu analisis merupakan bagian yang sangat penting dalam menentukan suatu hasil dari analisis di laboratorium (RamblaAlegre et al, 2012). Metode yang digunakan untuk membuktikan keabsahan dan kelayakan suatu metode adalah validasi dan verifikasi. Kata validasi berasal dari bahasa Latin validus yang berarti kuat, dan menunjukkan bahwa sesuatu telah terbukti benar, berguna dan dapat diterima (Araujo, 2009). International Organization for Standardization (ISO) dalam ISO 8402:1994 mendefinisikan validasi sebagai konfirmasi melalui proses pemeriksaan dan penyediaan bukti objektif bahwa sesuatu hal terbukti keabsahannya.

Tujuan akhir dari validasi metode adalah untuk memastikan bahwa setiap pengujian dalam analisis yang dilakukan akan menghasilkan hasil cukup dekat dengan nilai sebenarnya terhadap analat dalam suatu sampel yang sedang diuji (Rambla-Alegre et al, 2012). Selain itu validasi dilakukan pula untuk menjamin kualitas yang tinggi dari suatu pengujian, mendapatkan kepercayaan dari konsumen (Theodorsson, 2012), mendapatkan pengakuan keberterimaan produk di dunia internasional, persyaratan wajib bagi laboratorium uji untuk mendapatkan akreditasi ISO 17025, dan persyaratan wajib untuk meregistrasikan suatu produk (khusus obat dan pestisida) (International Organization of Standardization, 2017b).

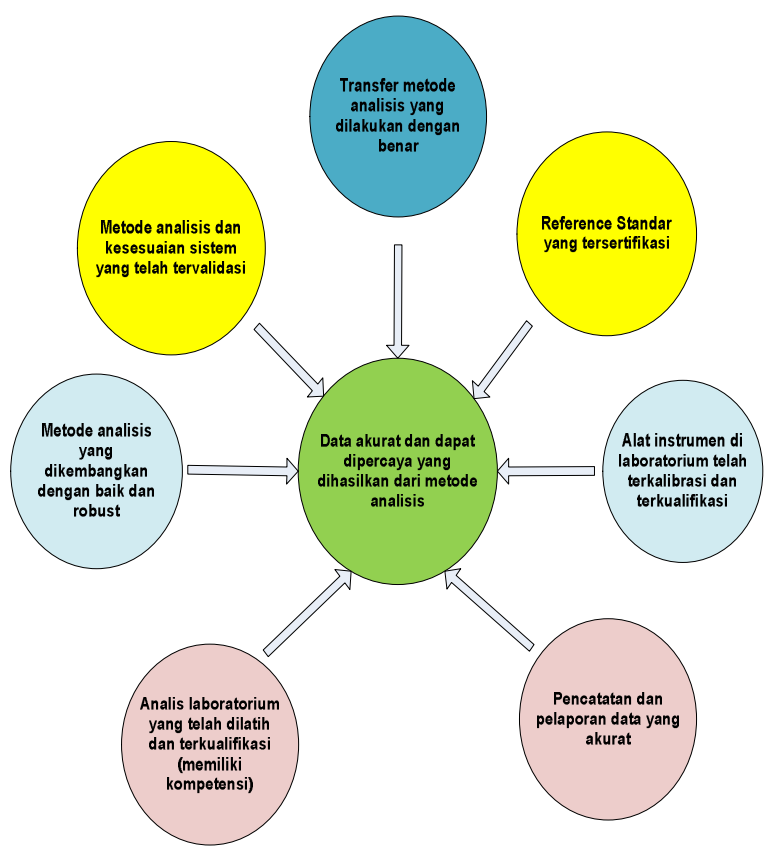

Gambar 1 Faktor yang menentukan hasil analisis di laboratorium (Rambla-Alegre et al., 2012).

Pada saat ini terdapat berbagai organisasi atau lembaga yang menerbitkan panduan mengenai metode validasi. Hal ini dikarenakan banyaknya metode analisis yang dikembangkan di berbagai negara (Rambla-Alegre et al., 2012). Pada validasi metode terdapat beberapa parameter yang digunakan diantaranya spesifitas, akurasi, presisi, repeatability, intermediate presisi, reproducibility, lineritas, range, limit deteksi (LOD), dan limit kuantitasi (LOQ) (Araujo 2009 ; RamblaAlegre et al., 2012). Parameter tersebut dilakukan sesuai dengan protokol standar yang kemudian dinilaikan terhadap kriteria yang telah ditentukan (Vassault et al., 2010). Pada suatu metode analisis tergantung pada aplikasi, jenis sampel, tujuan dari metode, dan pedoman dalam negeri, internasional atau peraturan yang berlaku (Lanovia, 2013)

Verifikasi merupakan suatu proses evaluasi atau konfirmasi yang bertujuan untuk memastikan kebenaran dan konsistensi pada suatu kegiatan atau proses sehingga persyaratan yang telah ditentukan dapat terpenuhi (Jacklin, 
2004 ; Mattocks, 2010). Sedangkan dalam metode uji, verifikasi metode merupakan bagian dari proses validasi metode yang dilakukan sebagai pembuktian bahwa metode analisis yang digunakan sebagai prosedur untuk mengukur suatu nilai, mampu dilakukan di laboratorium dan menghasilkan hasil yang baik dan diakui oleh pihak lain keabsahannya. Di samping itu verifikasi metode digunakan pula sebagai data kinerja laboratorium, karena setiap laboratorium memiliki peralatan dan kompetensi personel yang berbeda. Parameter yang umum diamati dalam verifikasi metode adalah akurasi dan presisi. Kedua parameter ini dianggap penting karena menunjukkan performa hasil analisis yang dilakukan apakah sesuai dengan target dan tujuan dari suatu proses analisis (International Organization of Standardization, 2017b)

Akurasi merupakan suatu uji yang dilakukan pada suatu metode apakah data yang dihasilkan mendekati nilai yang sebenarnya (Mattocks, 2010 ; Hasan et al., 2015) dalam hal ini menggunakan standar yang telah diketahui pasti nilainya atau lebih dikenal dengan nama certified reference material (CRM). Nilai perbedaan yang dihasilkan antara hasil pengujian dan nilai sebenarnya adalah tidak berbeda lebih dari pada rentang 98 $102 \%$ dari nilai sebenarnya pada CRM karena nilai konsentrasi dari sampel adalah $100 \%$ (Association of Official Agricultural Chemists, 2016).

Presisi merupakan keidentikan dan kedekatan diantara serangkaian pengulangan pengujian dari beberapa sampel homogen sehingga dihasilkan hasil pengujian yang memiliki nilai perbedaan yang kecil (Mattocks, 2010 American Standard Testing and Material, 2016). Presisi metode analisis umumnya dinyatakan sebagai simpangan baku relatif (RSD) atau koefisien variasi (KV) (Lanovia, 2013). Nilai RSD yang dapat diterima pada pengujian presisi terhadap sampel dengan konsentrasi $100 \%$ adalah $\leq 2 \%$ (American Standard Testing and Material, 2016). Nilai simpangan baku relatif atau koefisien variasi akan meningkat dengan menurunnya konsentrasi analit. Untuk memperoleh nilai koefisien variasi dapat dilakukan menggunakan persamaan Horwitz (Noerpitasari \& Nugroho, 2012). Presisi dapat dinyatakan baik jika memenuhi nilai koefesien variasi hasil percobaan lebih kecil dari nilai 2/3 koefisien Horwitz (Purnama \& Kusumaningtyas, 2014; Kurniyati, 2015; Kumalasari et al., 2017).

\section{METODE PENELITIAN}

\subsection{Bahan}

Bahan yang digunakan dalam penelitian ini adalah density reference standard yang diproduksi oleh Paragon Scientific Limited dengan kode produk
DEN50-03 lot number 1151703010. Selain itu, CPO sebagai bahan yang diuji densitasnya diperoleh dari pabrik kelapa sawit di daerah Bogor.

\subsection{Peralatan}

Peralatan yang digunakan dalam penelitian ini adalah waterbath merk NAPCO model 220 A, piknometer Gay Lusaac merk Rhema Glass kapasitas $10 \mathrm{~mL}$ (lihat Gambar 2), dan termometer infra merah dengan daerah suhu pengukuran -50 ${ }^{\circ} \mathrm{C}-360^{\circ} \mathrm{C}$.

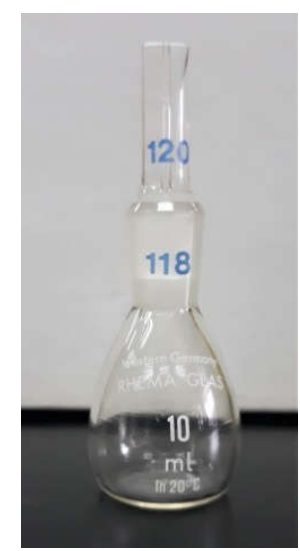

Gambar 2 Piknometer Gay Lusaac merk Rhema Glass kapasitas $10 \mathrm{~mL}$.

\subsection{Tahapan penelitian}

Pada penelitian ini dibagi menjadi beberapa tahap diantaranya adalah pertama melakukan kalibrasi dari piknometer yang digunakan untuk memperoleh nilai koefisien rata-rata ekspansi kubik ( $($ ), kemudian dilakukan uji akurasi dan uji presisi. Tahap terakhir dilakukan perhitungan terhadap hasil pengujian yang diperoleh.

\subsubsection{Kalibrasi piknometer}

Alat piknometer dikalibrasi pada suhu $20{ }^{\circ} \mathrm{C}$ dan $60{ }^{\circ} \mathrm{C}$ untuk memperoleh nilai koefisien rata-rata ekspansi kubik ( $\mathrm{Y}$ ) yang belum diketahui. Pada pengujian di suhu $20{ }^{\circ} \mathrm{C}$, piknometer dibersihkan dan keringkan secara menyeluruh kemudian ditimbang piknometer kosong dengan tutup $\left(\mathrm{m}_{1}\right)$. Kemudian disiapkan air suling dan dikondisikan pada suhu sekitar $5{ }^{\circ} \mathrm{C}$, air tersebut diisikan ke dalam piknometer dan ditutup (jangan sampai muncul gelembung udara). Piknometer yang telah berisi air tersebut dikondisikan hingga mencapai suhu $20{ }^{\circ} \mathrm{C}$ kemudian dibersihkan dari air yang meluap dan ditimbang. Untuk pengujian pada suhu $60^{\circ} \mathrm{C}$, disiapkan juga air suling kemudian diisikan air tersebut ke dalam piknometer dan ditutup (jangan sampai muncul gelembung udara). Piknometer yang telah terisi air ditempatkan ke dalam waterbath hingga mencapai suhu stabil $( \pm 1$ jam). Setelah stabil, suhu air di dalam waterbath dicatat $\left(\theta_{c}\right)$ diukur menggunakan termometer. Kemudian piknometer dikeluarkan dari waterbath, dan dibersihkan sampai kering. Setelah kering 
piknometer tersebut ditimbang $\left(\mathrm{m}_{2}\right)$. Volume piknometer dapat diketahui dengan perhitungan :

$\mathrm{V}_{\mathrm{c}}=\frac{\mathrm{m}_{2}-\mathrm{m}_{1}}{\rho_{\mathrm{w}}}$

keterangan:

$\mathrm{V}_{\mathrm{c}}=$ volume piknometer pada suhu $\theta_{\mathrm{c}}(\mathrm{mL})$

$\mathrm{m}_{1}=$ massa piknometer kosong (gram)

$\mathrm{m}_{2}=$ massa piknometer + air (gram)

$\rho_{\mathrm{w}}=$ nilai massa/volume air pada suhu $\theta_{\mathrm{c}}$ (gram/mL)

Kemudian nilai $\mathrm{Y}$ diperoleh dengan perhitungan :

$\gamma=\frac{\mathrm{V}_{c 2}-\mathrm{V}_{c 1}}{\mathrm{~V}_{c 1}\left(\theta_{2}-\theta_{1}\right)}$

keterangan :

$\mathrm{Y}=$ koefisien rata-rata ekspansi kubik $\left({ }^{0} \mathrm{C}-1\right)$

$\mathrm{V}_{\mathrm{c} 1}=$ volume piknometer pada suhu $\theta_{1}(\mathrm{~mL})$

$\mathrm{V}_{\mathrm{c} 2}=$ volume piknometer pada suhu $\theta_{2}(\mathrm{~mL})$

$\theta_{1}=$ suhu pada titik pengamatan $60^{\circ} \mathrm{C}$

$\theta_{2}=$ suhu pada titik pengamatan $20^{\circ} \mathrm{C}$

Volume piknometer dapat diperoleh dengan perhitungan :

$V_{d}=V_{c}\left[1+\gamma\left(\begin{array}{ll}\theta_{d} & \theta_{c}\end{array}\right)\right]$

keterangan :

$\mathrm{Y}=$ koefisien rata-rata ekspansi kubik $\left({ }^{0} \mathrm{C}-1\right)$

$\mathrm{V}_{\mathrm{d}}=$ volume piknometer pada suhu $\theta_{\mathrm{d}}(\mathrm{mL})$

$\mathrm{V}_{\mathrm{c}}=$ volume piknometer pada suhu $\theta_{\mathrm{c}}(\mathrm{mL})$

$\theta_{d}=$ suhu yang akan diketahui nilai volumenya $\left({ }^{0} \mathrm{C}\right)$

$\theta_{2}=$ suhu pada kalibrasi piknometer $\left({ }^{\circ} \mathrm{C}\right)$

\subsubsection{Uji densitas}

Ditimbang piknometer kosong (lihat Gambar 2) dengan tutup ( $\left.\mathrm{m}_{1}\right)$ kemudian dilepaskan tutup dari piknometer dan diisikan dengan sampel yang telah disiapkan. Dipasangkan kembali tutup piknometer (jangan sampai muncul gelembung udara) kemudian piknometer tersebut ditempatkan ke dalam waterbath hingga stabil pada suhu $50^{\circ} \mathrm{C}( \pm$ 2 jam). Setelah stabil kemudian dicatat suhu di dalam waterbath $\left(\theta_{\mathrm{d}}\right)$. Piknometer kemudian dikeluarkan dari waterbath dan dibersihkan dari sampel yang meluap dari bagian atas dan samping hingga kering. Piknometer kemudian dibiarkan mencapai suhu ambien, setelah itu ditimbang piknometer berisi sampel dengan tutup $\left(\mathrm{m}_{3}\right)$. Maka densitas sampel dapat diketahui dengan menggunakan perhitungan :

$\rho_{\theta}=\frac{\mathrm{m}_{3}-\mathrm{m}_{1}}{\mathrm{v}_{\mathrm{d}}}+\mathrm{k}\left(\theta_{d}\right.$

$\theta)$ keterangan :

$\rho_{\theta}=$ densitas $(\mathrm{g} / \mathrm{mL})$

$\mathrm{m}_{1}=$ massa piknometer kosong (dengan tutup) (gram)

$\mathrm{m}_{3}=$ massa piknometer + sampel (dengan tutup) (gram)

$\mathrm{V}_{\mathrm{d}}=$ volume piknometer pada suhu $\theta_{\mathrm{d}}(\mathrm{mL})$

$\theta_{\mathrm{d}}=$ suhu pengamatan piknometer $\left({ }^{\circ} \mathrm{C}\right)$

$\theta=$ suhu pengukuran sampel diamati $\left({ }^{\circ} \mathrm{C}\right)$.

$k=$ nilai rata-rata perubahan massa per volume minyak pada perubahan suhu $\left(\mathrm{g} / \mathrm{mL}^{\circ} \mathrm{C}\right)$ $\left(\mathrm{k}=0,00068 \mathrm{~g} / \mathrm{mL}^{0} \mathrm{C}\right)$

\subsubsection{Uji akurasi}

Uji akurasi dilakukan dengan tahapan sesuai pada poin 3.3.2 dengan certified reference material (CRM) yang telah diketahui nilai densitasnya sebagai sampel. Pengujian dilakukan sebanyak 6 kali, kemudian hasil yang diperoleh dibandingkan dengan nilai densitas yang terdapat pada sertifikat uji CRM. Nilai akurasi diperoleh dengan perhitungan:

$\%$ Akurasi $=\frac{\text { Hasil pengujian }}{\text { Nilai densitas } \mathrm{CRM}} \times 100 \%$

\subsubsection{Uji presisi}

Uji presisi dilakukan dengan tahapan sesuai pada poin 3.3.2 terhadap sampel CPO. Pengujian dilakukan sebanyak 20 kali, kemudian hasil yang diperoleh dibandingkan antar pengujian yang dilakukan dan dihitung nilai standar deviasi dan relative standard deviation (RSD) dengan menggunakan perhitungan :

$\mathrm{SD}=\sqrt{\frac{\sum(\mathrm{x}-\overline{\mathrm{x}})^{2}}{\mathrm{n}-1}}$

$\operatorname{RSD}(\%)=\frac{S D}{\bar{x}} \times 100$

dimana:

$\mathrm{x}=$ nilai densitas tiap ulangan

$\overline{\mathrm{x}} \quad=$ hasil rata-rata nilai densitas

$\mathrm{n} \quad=$ jumlah ulangan

$\mathrm{SD}=$ nilai standar deviasi

$\mathrm{RSD}=$ nilai simpangan baku relatif

Kemudian ditentukan nilai koefisien variasi Horwitz dengan perhitungan :

$\mathrm{KV}= \pm 2^{(1-0.5 \log \mathrm{C})}$

dimana:

$\mathrm{C}=$ fraksi dari konsentrasi sampel yang dianalisis 


\section{HASIL DAN PEMBAHASAN}

Hasil verifikasi metode pengujian densitas menggunakan standar ISO 6883:2017 tercantum pada Tabel 2 dan Tabel 3. Pada pengujian akurasi yang dilakukan sebanyak 6 (enam) kali pengulangan (Tabel 2) pada CRM diperoleh ratarata nilai densitas sebesar $0.8611 \mathrm{~g} / \mathrm{mL}$ dengan simpangan baku relatif sebesar $0.08 \%$. Hal ini menunjukkan bahwa pengujian akurasi mendekati nilai densitas sebenarnya yang telah dicantumkan pada sertifikat CRM yaitu sebesar $0.8659 \mathrm{~g} / \mathrm{mL}$ atau sebesar $99.44 \%(99.33-99.56 \%)$. Hal ini menunjukkan pengujian densitas menggunakan metode ISO 6883:2017 mendekati nilai yang sebenarnya (true value).

Tabel 2 Hasil uji akurasi.

\begin{tabular}{cccc}
\hline $\begin{array}{c}\text { Nilai densitas CRM } \\
\text { sebenarnya } \\
(\mathbf{g} / \mathbf{m L})\end{array}$ & Ulangan & $\begin{array}{c}\text { Hasil pengujian densitas CRM } \\
(\mathbf{g} / \mathbf{m L})\end{array}$ & $\begin{array}{c}\text { Akurasi hasil pengujian terhadap } \\
\text { nilai densitas CRM } \\
(\%)\end{array}$ \\
& 1 & 0.8621 & 99.56 \\
0.8659 & 2 & 0.8608 & 99.41 \\
& 3 & 0.8601 & 99.33 \\
& 4 & 0.8612 & 99.46 \\
& 5 & 0.8608 & 99.41 \\
\hline Rata-rata & 6 & 0.8616 & 99.50 \\
Standar deviasi & & 0.8611 & 99.44 \\
RSD (\%) & 0.0007 & 0.0008 \\
\hline
\end{tabular}

Nilai keberterimaan untuk uji akurasi pada suatu metode uji adalah berada dalam rentang 98 - $102 \%$ dibandingkan dengan nilai sebenarnya dari CRM yang digunakan sebagai pembanding (Association of Official Agricultural Chemists, 2016). Pada pengujian presisi yang dilakukan pada sampel CPO sebanyak 20 kali ulangan (Tabel 3) diperoleh nilai rata-rata densitas CPO sebesar $0.8867 \mathrm{~g} / \mathrm{mL}(0.8771-0.8889 \mathrm{~g} / \mathrm{mL})$ dengan simpangan baku relatif sebesar $0.35 \%$. Berdasarkan American Standard Testing and Material tahun 2016 nilai simpangan baku relatif yang diperoleh kurang dari $2 \%$ menunjukkan metode tersebut memiliki presisi atau keterulangan yang baik. Nilai simpangan baku relatif pada uji presisi yang diperoleh juga berada di bawah dari nilai simpangan baku relatif Horwitz, hal ini menunjukkan bahwa data yang dihasilkan memiliki sebaran yang tidak terlampau jauh. Sebaran data dari pengulangan hasil uji akan memberikan kehandalan dari suatu metode mengingat metode tersebut akan digunakan secara berulang dan rutin di laboratorium.

Tabel 3 Hasil uji presisi.

\begin{tabular}{ccccccc} 
No & $\begin{array}{c}\text { Hasil pengujian densitas } \\
\text { sampel CPO }\end{array}$ & Rata-rata & $\begin{array}{c}\text { Standar } \\
\text { deviasi }\end{array}$ & $\begin{array}{c}\text { RSD } \\
(\%)\end{array}$ & $\begin{array}{c}\text { RSD Horwitz } \\
\text { (\%) }\end{array}$ & $\begin{array}{c}\text { 2/3 RSD Horwitz } \\
\text { (\%) }\end{array}$ \\
\hline 1 & 0.8793 & & & & & \\
2 & 0.8771 & & & \\
3 & 0.8874 & & & \\
4 & 0.8882 & & & \\
5 & 0.8855 & & & \\
6 & 0.8894 & & & \\
7 & 0.8869 & & & \\
8 & 0.8885 & & & & \\
9 & 0.8869 & & & \\
10 & 0.8886 & 0.0031 & 0.35 & \\
11 & 0.8857 & & & \\
12 & 0.8886 & & & \\
13 & 0.8857 & & & & \\
14 & 0.8881 & & & \\
15 & 0.8874 & & & \\
16 & 0.8886 & & & \\
17 & 0.8866 & & & \\
18 & 0.8887 & & & & \\
19 & 0.8868 & & & \\
20 & 0.8889 & & & & \\
\hline
\end{tabular}


Faktor kritis pada metode ISO 6883:2017 dalam melakukan pengujian densitas adalah pencatatan suhu aktual saat proses pengujian. Nilai suhu sangat menentukan nilai densitas karena menurut Baroutian et al. (2010) densitas merupakan suatu fungsi dari suhu. Hal ini memiliki arti bahwa setiap perubahan suhu akan menyebabkan perubahan nilai densitas. Oleh karena itu, pencatatan suhu air sebagai medium transfer panas pada waterbath harus tepat.

Kesalahan pencatatan suhu akan menyebabkan kesalahan negatif ataupun positif pada proses pengujian.Berdasarkan hasil uji akurasi dan presisi nilai densitas CPO menggunakan metode ISO 6883:2017, metode tersebut dapat menjadi acuan untuk melakukan pengujian nilai densitas pada produk CPO. Di Indonesia, terdapat SNI 01-2901-2006 tentang minyak kelapa sawit mentah (crude palm oil), namun dalam spesifikasinya belum diatur mengenai nilai densitas.

Hasil penelitian ini dapat menjadi rekomendasi untuk merevisi SNI 01-2901-2006 mengenai CPO. Standar SNI tentang CPO tersebut dapat menjadi acuan bagi setiap produsen CPO dalam melakukan produksi. Penggunaan Metode uji yang telah tervalidasi dan terverifikasi dalam melakukan pengujian dapat meningkatkan keberterimaan dari dunia internasional atas hasil pengujian karakteristik mutu CPO yang diperdagangkan

\section{KESIMPULAN}

Metode ISO 6883:2017 tentang animal and vegetable fats and oils - determination of conventional mass per volume (litre weight in air) dapat diaplikasikan untuk melakukan pengujian densitas pada sampel CPO. Hal ini dibuktikan dengan hasil uji akurasi yaitu $99.44 \%$ dan simpangan baku relatif sebesar $0.35 \%$ pada uji presisi yang sesuai dengan syarat keberterimaan suatu metode uji dapat dikategorikan memiliki performa yang baik. Metode ini pula dijadikan sebagai acuan dalam penyusunan spesifikasi dalam Standar Nasional Indonesia (SNI) tentang CPO. Selain itu, untuk beberapa uji lanjutan seperti uji ketidakpastian dan uji banding antar laboratorium perlu dilakukan untuk lebih memperkuat kualitas dan performa dari metode uji tersebut.

\section{UCAPAN TERIMA KASIH}

Penulis mengucapkan terima kasih kepada Southeast Asian Food and Agricultural Science and Technology (SEAFAST) Center Institut Pertanian Bogor atas fasilitas yang diberikan dan Badan Pengelola Dana Perkebunan Kelapa Sawit (BPDPKS) atas dana yang mendukung penelitian ini.

\section{DAFTAR PUSTAKA}

Abdullah, R. (2011). World palm oil supply, demand, price, and prospects : focus on Malaysian and Indonesian palm oil industries. Oil Palm Industry Economic Journal. 11(2) :13-25.

Adinugroho, T. P., Susanto, D. A., Mulyono, A. B., Isharyadi, F., \& Suminto, S. (2016). Kesiapan Lembaga Penilai Kesesuaian (LPK) di Indonesia Menghadapi Masyarakat Ekonomi ASEAN (MEA). Jurnal Standardisasi, 17(2), 109116.

American Society for Testing and Materials. 2016. ASTM D5002-16 : Standard test method for density and relative density of crude oils by digital density analyzer. West Conshohocken (US) : ASTM International.

American Standard Testing and Material. (2018). ASTM D4052-18. Standard test method for density, relative density, and API gravity of liquids by digital density meter. West Conshohocken (US) : ASTM International.

Andarwulan, N. Kusnandar, F. \& Herawati, D. (2014). Pengelolaan Data Analisis Pangan. Tangerang Selatan (ID): Universitas Terbuka.

Araujo, P. (2009). Key aspects of analytical method validation and linearity evaluation. Journal of Chromatography $B, 877(23), 2224-2234$.

Association of Official Agricultural Chemists. (2016). Appendix F: Guidelines for Standard Method Performance Requirements. Gaithersburg (US) : AOAC.

Ayustaningwarno, F. (2012). Proses pengolahan dan aplikasi minyak sawit merah pada industri VITASPHERE, 2(1), 1-11. pangan. Journal

Badan Pusat Statistik. (2017). Statistik Kelapa Sawit Indonesia 2017. Jakarta (ID) : BPS

Badan Standardisasi Nasional. (2006). SNI 012901-2006. Minyak kelapa sawit mentah (crude palm oil). Jakarta (ID) : BSN.

Baroutian, S., Aroua, M. K., Raman, A. A., \& Sulaiman, N. M. (2009). Viscosities and densities of binary and ternary blends of palm oil+ palm biodiesel+ diesel fuel at different temperatures. Journal of 
Chemical \& Engineering Data, 55(1), 504-507.

Bureau of Indian Standards. (2018). IS 8323.2018. Palm Oil-Spesification. New Delhi (IND) : BIS

China National Standards. (2009). GB 156802009. Palm oil. Shenzhen (CN) : CNS.

Chuayjuljit, S., Sangpakdee, T., \& Saravari, O. (2017). Processing and properties of palm oil-based rigid polyurethane foam. Journal of Metals, Materials and Minerals, 17(1). 17-23

Codex Allimentarius. (2017). CODEX STAN 210-1999. Codex standard for named vegetable oils. Roma (IT) : Codex.

Department of Standards Malaysia. (2007). MS 814 : 2007. Palm oil specification (second revision). Selangor (MY) : Standards Malaysia.

Esteban, B., Riba, J. R., Baquero, G., Rius, A., \& Puig, R. (2012). Temperature dependence of density and viscosity of vegetable oils. Biomass and bioenergy, 42, 164-171.

Hasan, M., Kayesh, R., Begum, F., \& Rahman, S. M. (2015). Transition metal complexes of naproxen: synthesis, characterization, forced degradation studies, and analytical method verification. Journal of analytical methods in chemistry, 2016, 110.

Hasibuan, H.A. (2012). Kajian mutu dan karakteristik minyak sawit Indonesia serta produk fraksinasinya. Jurnal Standardisasi, 14(1), 13-21.

International Organization of Standardization. (1994). ISO 8402:1994 - Quality management and quality assurance Vocabulary. Geneva $(\mathrm{CH})$ : ISO.

International Organization of Standardization. (2017a). ISO 6883:2017 - Animal and vegetable fats and oils - Determination of conventional mass per volume (litre weight in air). Geneva ( $\mathrm{CH})$ : ISO.

International Organization of Standardization. (2017b). ISO/IEC 17025:2017 - General requirements for the competence of testing and calibration laboratories. Geneva $(\mathrm{CH})$ : ISO.

Jacklin, S., Schumann, J., Gupta, P., Lowry, M., Bosworth, J., Zavala, E., Hayhurst,K., Celeste, B. \& Belcastro, C. (2004). Verification, validation, and certification challenges for adaptive flight-critical control system software. In AIAA Guidance, Navigation, and Control Conference and Exhibit (p. 5258).
Kadir, I. A., Jurid, L. S., \& Zubairi, S. I. (2017). Physico-Chemical properties of recycled refined, bleached and deodorized (RBDPO) palm olein: Which cycle should the olein considered spoilage?. Jurnal Teknologi, 79(4).

Kumalasari, A., Panggabean, A. S., \& Akkas, E. (2017). Pengembangan Metode Rapid Test dalam Penentuan Ash Content dan Calorific Value Batubara di Laboratorium PT Jasa Mutu Mineral Indonesia. Jurnal Atomik, 2(1), 121-127.

Kurniyati, F., \& Saefumillah, A. (2015). Validasi Metode Analisis Bahan Pembanding Sekunder Anhidrotetrasiklin Hasil Transformasi In Situ Tetrasiklin Hidroklorida dengan Asam Hidroklorida. Sainsmat, 3(1).

Lanovia, T. (2013). Validasi metode weißhaar yang dimodifikasi untuk analisis 3chloropropane-1,2-diol (3-mcpd) dan esternya pada minyak goreng sawit [tesis]. Bogor (ID) : Institut Pertanian Bogor.

Mariati, R. (2009). Pengaruh produksi nasional, konsumsi dunia dan harga dunia terhadap ekspor Crude Palm Oil (CPO) di Indonesia. Jurnal EPP, 6(1), 30-35.

Mattocks, C. J., Morris, M. A., Matthijs, G., Swinnen, E., Corveleyn, A., Dequeker, E., Müller, CR., Pratt, V. \& Wallace, A. (2010). A standardized framework for the validation and verification of clinical molecular genetic tests. European Journal of Human Genetics, 18(12), 1276.

Nasution, A., Fajri, F., \& Sofyan, S. (2015). Analisa Pola Produksi Kelapa Sawit Dan Keseimbangannya Terhadap Pabrik Kelapa Sawit Di Pantai Barat Aceh. Jurnal Agrisep, 16(2), 70-76.

Noerpitasari, E., \& Nugroho, A. (2012). Validasi Metode Analisis Unsur Tanah Jarang (Ce, Eu, Tb) dengan Alay ICP-AES Plasma 40. dalam: Semin. Nas. VIII SDM Teknol. Nukl, 347-352.

Purnama, P., \& Kusumaningtyas, D. I. (2014). Penentuan Batas Deteksi (LOD) Dan Batas Kuantitasi (LOQ) Pada Pengukuran Fosfat $\left(\mathrm{PO}_{4}-\mathrm{P}\right)$ dalam Air Tawar dengan Metode Asam Askorbat. Buletin Teknik Litkayasa Sumber Daya dan Penangkapan, 12(1), 71-75.

Rambla-Alegre, M., Esteve-Romero, J., \& Carda-Broch, S. (2012). Is it really necessary to validate an analytical method or not? That is the 
question. Journal of Chromatography A, 1232, 101-109.

Tan, C.P., \& Nehdi, I.A. (2012). The physicochemical properties of palm oil and its components. Di dalam Lai OM, Tan CP, Akoh CC (ed). Palm oil: Production, processing, characterization, and uses. Urbana (US) : AOCS.

Theodorsson, E. (2012). Validation and verification of measurement methods in clinical chemistry. Bioanalysis, 4(3), 305320.

Ulfah, M., Riswanto, A., \& Ngatirah, N. (2016). Karakteristik Minyak Campuran Red

Palm Oil dengan Palm Kernel
Olein. Agritech, 36(2), 145-153.

Vassault, A., Hulin, A., Chapuzet, E., Arnaud, J., \& Giroud, C. (2010). Verification/validation of the performances of analytical method. In Annales de biologie clinique (Vol. 68, pp. 247-294).

Widyaningtyas, D., \& Widodo, T. (2017). Analisis pangsa pasar dan daya saing CPO Indonesia di Uni Eropa. Jurnal Manajemen Daya Saing, 18(2), 138-145. 